\title{
РЕЙТИНГ ЯК СКЛАДОВА СИСТЕМИ УПРАВЛІННЯ ЯКІСТЮ ПІДГОТОВКИ ЛІКАРІВ І ПРОВІЗОРІВ
}

\author{
Б. С. Зіменковський, М. Р. Гжегоцький, І. І. Солонинко \\ Львівський національний медичний університет імені Данила Галицького
}

\section{RATING AS A CONSTITUENT OF QUALITY MANAGEMENT SYSTEM IN MEDICAL AND PHARMACEUTICAL TRAINING}

\author{
B. S. Zimenkovskyi, M. R. Hzhehotskyi, I. I. Solonynko \\ Lviv National Medical University by Danylo Halytskyi
}

\begin{abstract}
У статті проаналізовано досвід та ефективність рейтингової системи оцінювання у Львівському національному медичному університеті імені Данила Галицького в умовах кредитно-модульної системи організації навчального процесу, наведено основні проблеми і шляхи вдосконалення якості підготовки фахівців.
\end{abstract}

The article adduces the experience and effectiveness of rating estimation system in Danylo Halytskyi Lviv National Medical University according to the European Credit Transfer System of Education. The essential problems and ways of quality improvement in specialists' training have been analyzed in the article.

Вступ. Головним стратегічним завданням вищого навчального закладу завжди було і залишається забезпечення високої якості підготовки фахівців. Нові вимоги і реалії сучасної медичної і фармацевтичної освіти, інтеграція вітчизняної вищої освіти у світовий освітній простір вимагають її оновлення та приведення якості національної медичної освіти до європейських стандартів із збереженням кращих національних особливостей і традицій. Важливою складовою технологічного переоснащення організаційних моделей сучасного навчально-виховного процесу є оцінювання якості освіти, визначення показників якості підготовки фахівця, діагностика навчальних досягнень студентів. Формальні і прості методи діагностики знань на сучасному етапі замінені інтенсивними комплексними системами, які покликані забезпечувати об'єктивність оцінювання навчальних досягнень студентів, підвищувати мотивацію до плідної праці впродовж всього періоду навчання. Разом з цим, стрімке впровадження кредитно-модульної системи організації навчального процесу не забезпечене у повній мірі нормативно-правовою базою, яка б регламентувала діяльність вищих навчальних закладів у нових умовах. Тому навчальні заклади мають можливість самостійного пошуку свого місця у європейському освітньому просторі, з урахуванням Європейських стандартів і рекомендацій забезпечення якості освіти. За допомогою освітнього моніторингу робляться спроби проаналізувати ефективність (с) Б. С. Зіменковський, М. Р. Гжегоцький, І. І. Солонинко технологій навчання, виділити чинники, що впливають на якість навчання, отримати об'єктивний зріз стану знань та його відповідність рейтинговій оцінці. У навчальній діяльності рейтинг служить основою для побудови різноманітних шкал оцінок і передбачає визначення рівня оволодіння студентами змістом навчального матеріалу, модуля, цілісного курсу, сформованості умінь і навичок [1-4].

Основна частина. У Львівському національному медичному університеті імені Данила Галицького рейтингова система оцінювання, як і кредитно-модульна система організації навчального процесу використовується, починаючи з 2005-2006 навчального року, відповідно до запропонованого МОЗ України Навчального плану підготовки фахівців освітньо-кваліфікаційного рівня “спеціаліст” кваліфікації “лікар” та Тимчасової інструкції з оцінювання навчальної діяльності студентів при кредитно-модульній системі організації навчального процесу.

Характерними рисами нової технології є структурування навчальних дисциплін на модулі, які розглядаються як логічно завершена частина навчальної програми. Впроваджено залікові кредити ECTS як одиниці виміру навчального навантаження студента, необхідного для засвоєння навчальної дисципліни. Кожен модуль передбачає виконання студентом певного обсягу роботи (аудиторної, практичної, самостійної та індивідуальної) і завершується підсумковим модульним контролем. 3 графіка навчального 
процесу вилучено екзаменаційні сесії, оскільки здійснюється контроль засвоєння студентом кожного модуля навчальної дисципліни.

Для оцінювання використовується 200-бальна шкала, яка інтегрально характеризує успішність і знання студентів та дає можливість детально розділити їх на групи, встановлені шкалою ECTS. При цьому загальна сума балів розподіляється між результатами оцінювання поточної успішності та підсумкового модульного контролю у співвідношенні $60 \%$ : $40 \%$.

Оцінка за модуль визначається як сума балів поточної навчальної діяльності та балів за підсумковий модульний контроль, які виставляються при оцінюванні теоретичних знань та практичних навичок відповідно до переліків, визначених програмою дисципліни. Кількість балів, яку студент набрав з дисципліни, визначається як середнє арифметичне кількості балів 3 усіх модулів дисципліни. Ранжування з присвоєнням оцінок “'A”, “B”, “C', “'D”, “Е” проводиться для студентів даного курсу, які навчаються за однією спеціальністю, і успішно завершили вивчення дисципліни.

Перевагами цієї інноваційної педагогічної системи є обов'язкове вивчення та оцінювання кожного компонента дидактичної системи, чітка послідовність викладання і організація контролю засвоєння навчального матеріалу в дискретно-неперервному полі відповідно до встановлених навчальною програмою критеріїв оцінювання.

Досвід показує, що рейтинговий контроль дозволяє персоналізувати і диференціювати оцінювання навчальних досягнень студента на всіх етапах процесу навчання (семестр, навчальний рік, увесь період навчання).

Паралельно $з$ рейтинговою відносною шкалою ECTS використовується абсолютна шкала конвертації балів, яка дозволяє визначити середній бал для розрахунку стипендій та зведених академічних показників з використанням еквівалента оцінки за національною чотирибальною шкалою (табл. 1).

Необхідно відзначити, що шкала ECTS та чотирибальна шкала є незалежними і тому оцінка ECTS y традиційну чотирибальну шкалу не конвертується.

У таблицях 2 i 3 наведено приклади конвертації балів в оцінки за відносною шкалою ECTS та абсолютною шкалою з дисципліни "Медична хімія" для студентів 1-го курсу спеціальності “Лікувальна справа".

Таблиця 1. Абсолютна шкала конвертації балів

\begin{tabular}{|c|c|}
\hline Бали & Оцінка за чотирибальною шкалою \\
\hline Від 170 до 200 балів & 5 \\
\hline Від 140 до 169 балів & 4 \\
\hline Від 139 до мінімальної кількості балів, яку повинен набрати студент & 3 \\
\hline Нижче мінімальної кількості балів, яку повинен набрати студент & 2 \\
\hline
\end{tabular}

Таблиця 2. Результати ранжування успішності студентів за шкалою ECTS

\begin{tabular}{|c|c|c|c|c|}
\hline \multirow{2}{*}{ Оцінка ЕСТS } & \multicolumn{2}{|c|}{ Граничні значення балів } & \multirow{2}{*}{$\begin{array}{c}\text { Статистичний } \\
\text { показник у \% }\end{array}$} & \multirow{2}{*}{ Кількість студентів } \\
\cline { 2 - 3 } & від & до & 10,5 & 46 \\
\hline А & 170,5 & 194,0 & 25,7 & 112 \\
\hline $\mathrm{B}$ & 153,0 & 170,0 & 30,0 & 131 \\
\hline $\mathrm{D}$ & 137,5 & 152,5 & 25,4 & 111 \\
\hline $\mathrm{E}$ & 125,0 & 137,0 & 8,4 & 36 \\
\hline
\end{tabular}

Таблиця 3. Результати конвертації успішності за абсолютною шкалою

\begin{tabular}{|c|c|c|c|c|}
\hline \multirow{2}{*}{ Традиційна оцінка } & \multicolumn{2}{|c|}{ Граничні значення балів } & \multirow{2}{*}{ студентів } & \multirow{2}{*}{ Кількість студентів } \\
\cline { 2 - 3 } & від & до & 11,4 & 50 \\
\hline Відмінно & 170,0 & 194,0 & 51,6 & 225 \\
\hline Добре & 140,0 & 169,0 & 37,0 & 161 \\
\hline Задовільно & 122,0 & 139,0 & \\
\hline
\end{tabular}

Порівняльний аналіз наведених результатів показує, що одночасне застосування відносної шкали ECTS та абсолютної шкали конвертації 200 балів у національну шкалу неодмінно супроводжується певним відхиленням в оцінках. Причому різниця в оцінках може значно збільшуватись у випадку масового отримання студентами дуже високих або, навпаки, дуже низьких балів з дисципліни.
Абсолютна шкала дозволяє реально оцінити загальний стан підготовки студентів 3 дисципліни, але у багатьох випадках відсутня кореляція щодо статистичного показника ECTS. Це спонукає кафедри до здійснення постійного моніторингу успішності за обома шкалами та коригування контрольних заходів у напрямку цільового співвідношення між різними позитивними оцінками. Іншими словами, система ECTS 
вимагає від університету постійно слідкувати за своєю культурою і практикою оцінювання. У протилежному випадку принципова різниця між національною та ECTS шкалами призведе до проблеми “подвійних" оцінок (оцінка ECTS та традиційна, які відрізнятимуться; наприклад: А i “добре”, чи ще гірше: А і “"задовільно”), що остаточно буде відображено у додатку до диплома і може вплинути на репутаційну оцінку якості роботи навчального закладу.

Слід відмітити, що накопичувальна багатобальна шкала є елементом системи вищого порядку, а їі використання має значні переваги і дає можливість отримати детальні первинні дані, придатні для визначення рейтингу студентів. Використання шкали ECTS покликане забезпечити якість вищої освіти, запровадження стандартів, рекомендацій і основних інструментів Свропейського простору вищої освіти, що сприятимуть сумісності і порівнянності оцінювання відповідних періодів навчання. Окрім цього, для розробки навчальних програм, зорієнтованих на багатобальну шкалу, у медичних вищих навчальних закладах затрачені значні інтелектуальні та матеріальні ресурси. В той же час виставлення традиційних оцінок за чотирибальною шкалою відбувалось і раніше та не потребує складних взаємоперетворень оцінок в бали, а потім балів у ці ж оцінки.
Анкетування студентів показало - більшість 3 них вважають, що рейтингова система оцінювання та визначення академічного рейтингу активізує навчальну роботу впродовж семестру, спонукає до систематичної та самостійної праці, розширює можливості для розвитку творчих здібностей, індивідуалізує навчання. Рейтинг робить систему оцінювання більш гнучкою та об' єктивною, забезпечує змагальність у навчанні та здорову конкуренцію між студентами і є підставою не лише для призначення іменних стипендій, пріоритету на поселення у гуртожиток, але й для переведення 3 контрактної форми навчання на бюджетну та навпаки.

На наш погляд, при оцінюванні успішності студентів 3 дисциплін достатньо використовувати єдину шкалу, яка б встановлювала взаємозв'язок між рейтинговим показником з дисципліни, національною шкалою оцінювання знань і шкалою оцінок ECTS. Нормативно-правовою базою у вирішенні цього питання $\epsilon$ лист МОН України від 26.02.2010 р. №1/9-119, у якому надано для практичного використання "Методичні рекомендації щодо запровадження європейської кредитно-трансферної системи та її ключових документів у вищих навчальних закладах”. Відповідно до пункту 14 “Оцінювання знань” - єдина розширена шкала при 200-бальній системі оцінювання може бути представлена таким чином (табл. 4).

Таблиця 4. Шкала оцінювання і розподілу рейтингових балів

\begin{tabular}{|c|c|c|}
\hline Оцінка ЕСТS & Статистичний показник & Оцінка за розширеною шкалою \\
\hline A & $10 \%$ & відмінно \\
\hline B & $25 \%$ & дуже добре \\
\hline C & $30 \%$ & добре \\
\hline D & $25 \%$ & задовільно \\
\hline E & $10 \%$ & достатньо \\
\hline FX & не зарахований ПМК & незадовільно \\
\hline F & не допущений до ПМК & неприйнятно \\
\hline
\end{tabular}

Висновки. Таким чином, використання запропонованої шкали оцінювання спростить розуміння результатів навчання та забезпечить безперешкодну конвертацію оцінок з однієї системи в іншу. Рейтингова система оцінювання якості підготовки фахівця є важливим кроком щодо інтенсифікації і оптимізації навчально-виховного процесу у вищій школі. У сучасних умовах послаблення позицій масової середньої школи та поглиблення демографічної кризи модуль-

\section{Лiтература}

1. Булах I. С. Проблеми оцінювання знань студентів у контексті вимог Болонської декларації/І. Є. Булах, О. П. Волосовець, М. Р. Мруга // Медична освіта. -2011.-№2.-С. 20-22.

2. Андрущенко В. Модернізація педагогічної освіти відповідно до викликів XXI століття / В. Андрущенко, В. Боднар но-рейтингова система оцінювання навчальних досягнень студентів залишається оптимальною педагогічною технологією, яку необхідно розвивати з урахуванням наукового і педагогічного потенціалу професорськовикладацького складу та особливостей контингенту студентів. Рейтинг є не лише одним з елементів оцінювання якості підготовки фахівців в цілому, але й способом оцінювання навчальним закладом власної діяльності та зовнішнього його визнання.

// Вища освіта України. - 2009. - № 2. - С. 17-23.

3. ПавловськийК. Трансформації вищоїосвітив ХХІ столітті : польський погляд /К. Павловський. - Київ, 2005.-228 с.

4. Василюк А. Проблеми аналізу освітніх реформ / А. Василюк // Вища школа. - 2009. - № 9. - С. 76-82. 